\title{
Pazarlama İletişim Aracı Olarak Yeni Medyada Dijital Etkileyiciler: Vloggerların Karakteristik Özellikleri ve Bilgi Birikimi Tiplerinin Vlogger İtibarına Etkisi Üzerine Bir Araştırma
}

\author{
DOI: 10.26466/opus. 526579
}

D. Zeynep Bayazit* - Beril Durmuş - Figen Yıldırım***

*Dr. Öğr. Üyesi, İstanbul Ticaret Üniversitesi İşletme Fakültesi, İstanbul / Türkiye

E-Posta: zbayazit.@ticaret.edu.tr

ORCID: $\quad \underline{0000-0003-3884-7349}$

** Prof. Dr., Marmara Üniversitesi, İşletme Fakültesi, İstanbul/ Türkiye

E-Posta: $\underline{\text { bdurmus@marmara.edu.tr }}$

ORCID: $\quad$ 0000-0002-9679-9608

${ }^{* * * *}$ Doç. Dr. İstanbul Ticaret Üniversitesi, İşletme Fakültesi, İstanbul/Türkiye

E-Posta: figen@ticaret.edu.tr

ORCID: $\underline{0000-0002-9247-2245}$

Öz

Günden güne gücü artan yeni medyanın önemli oyuncuları olarak vloggerlar markaların iletişim çabalarına destek olurken, kendilerine bağlı kitlelerin satın alma kararlarım oluşturmalarında etkin rol oynamaktadırlar. Vloggerların karakteristik özelliklerinin yanında sundukları bilgi birikimin kaynağı ve bunu nasıl bir ruh halinde sunduklarl, vlogger tercihini ve sonrasinda kendilerine duyulan itibar algısını etkilemektedir. Bu çalışmada iletişim çabalarında vlogları kullanacak markaların özellikle seçilen vloggerm bilgi birikimi tipleri ve karakteristik özelliklerinin vloggerm itibar oluşumunda ne kadar etkili olduğu anlaşılmaya çalışılmıştır. Bu sebeple, kolayda örneklem yöntemi kullanılarak 224 katılımcıyla yapılan anket veri toplama yöntemiyle söz konusu iliş̧i irdelenmiştir. Sonuç olarak literatürde henüz az sayıda olan vlog üzerine yapılacak olan gelecekteki çalışmalara ışık tutması amacıyla vloggerların iletişim aracı olarak seçimi/kullanımında, içerik yaratılmasında marka ile özdeşleşen iletişim stratejilerinin sunulmasının önemi vurgulanmaktadır.

Anahtar Kelimeler: Dijital etkileyiciler, yeni medya, teknik/uzmanlık kaynaklı bilgi, deneyim kaynakl bilgi birikimi, vlogger 


\title{
Digital Influencers in New Media as a Marketing Communication Tool: A Research About The Effects of Vloggers' Characteristics and Types of Knowledge on Vlogger' Reputation
}

\begin{abstract}
The growing power of vloggers, new players of new media, and their effective influence on their connected network's buying decisions have emerged as a new communication tool for brands. Vloggers' characteristics and knowledge have important relationship with vloggers' reputation. The purpose of this paper is to investigate how consumers respond to this type of brand communication activity (vlogging), and evaluate its effects on the choosen vloggers' reputation. A survey with convenience sampling involving 224 vlog audiences as participants was analyzed in the empirical study to investigate the relationship between the previously mentioned variables. As a result, with the aim of being light for future studies about vlogs; in case of using vloggers as a marketing communication tool, it must be well understood that creating/choosing synergetic content with the elements of brand communication mix is important.
\end{abstract}

Keywords: Authoritative knowledge, new media, digital influencers, vlogger, engagement knowledge 


\section{Giriş}

Günümüzde, pazarlama iletişimi markaların geleneksel ve yeni medya araçlarını birarada kullanarak holistik (bütünsel) bir anlayışla içerik geliştirmeleri sonucunda büyük ilerleme kaydetmiştir. Klasik anlayş̧tan uzaklaşarak müşteriye, günlük hayatının içerisinde/özelinde interaktif olma motivasyonu yaratılmakta; sadece tek yönlü mesaj bekleyen pasif konumdan çıkartıp etkileşimin yoğunlaştığı, iletişim mesajını kendi kendine oluşturabildiği ve bunu diğerleriyle paylaşma imkanı verildiği aktif rol alınan sosyal ortamlar hazırlanmaktadır. Teknolojinin sağladığ bilgi akışının uzantısında farklı medya araçları ortaya çıkmaktadır. Öncelerde ağ günlüğü olarak ortaya çıan bloglar şimdilerde yerini birden fazla duyumuza aynı anda hitap eden video bloglarına(vlog) bırakmıştır. Vlogların yayılımı ve popülaritesi içerik yapılanması ve yaratıcısının (vlogger) özelliklerine göre değişmektedir. Vloggerlar fiziksel/duygusal ilgi çekicilikleri, kullandıkları dil ve ruh halleri ile bireylerin dikkatini anlatılmak istenilen içeriğe çekmektedirler. Sağladığı bilginin kaynağına bakılmaksızın öncelikle yaratılan atmosfere göre izleyici olup olmama kararı veren bireyler, çoğunlukla sosyal medyanın viral etkisi ile pekişen dijital etkileyicilerin tavsiyelerinin tesiri altında kalarak satınalma kararlarını vermektedirler.

Markalar bu gücü farketmeye başladıklarından beri yatırım yapacakları vlog içeriğinin yanında vloggerın bilgi birikiminin nereden kaynaklandığını, karakteristik özelliklerinin sonrasında nasıl bir itibarının olduğunu araştırmaya ve sonrasında kendileri ile işbirliği çabası içerisine girmeye karar vermektedirler. İletişimde gürültü kavramının oluşmaması adına bütünleşik olarak yaratılacak içeriklerin tüm medya araçlarından benzer çağrışım ve içeriklerle verilmesi iletişim stratejilerinin etkinliği açısından son derece önemlidir. Üstelik sosyal medyanın viral etkisinin pozitif olduğu kadar, negatif ağızdan ağıza iletişim riskinin de olduğu gözönünde bulundurulmalıdır.Vlogların her ne kadar teknik/uzman bilgiye sahip kişiler tarafından yönetilmesi beklenirken, son dönemde tamamen deneyime dayalı bilgi birikiminden ilerleyen gerçek olduğu daha çok hissedilen vloggerlara doğru kaydığı görülmektedir. Hiç kuşkusuz kategorinin ihtiyacı, pazarın niteliği ve müşterinin beklentilerine göre değişen bu bilgi birikimi tipi tercihi itibarın oluşturulmasında 
da önemli bir etkiye sahiptir. Örneğin daha çok uzmanlık isteyen sağlıkla ilgili bir konuda itibarın yüksek olması adına sözkonusu alanda eğitim almış kişiler tercih edilirken, kullanım kolaylığının vurgulandığı ürünlerde "o yapıyorsa ben de yapabilirim" motivasyonu veren deneyimden gelen bilgi satınalmayı daha çok destekleyebilmektedir. Vloggerın sunduğu ortam ve karakter özelliği, verilen bilginin inandırıcılığını ve daha çok benimsenmesini sağlamaktadır.

\section{Kavramsal Çerçeve}

İşletmeler internet ile gelişen yeni medya araçlarını stratejik pazarlama iletişiminin ayrılmaz bir parçası olarak görmektedir. Bu anlayışla gelişen sosyal platform ve topluluklarda etkileşim artmakta ve önemli bir güç olarak kullanılmaktadır. Sosyal paylaşımlarda etkileyen iticü güçlerin başında ünlülerin yanında sosyal medyada kendi kendilerine topluluklarını yaratan sonradan ünlenen bireylerin, blogger veya daha yeni versiyonları olan vlogger gibi dijital etkileyicilerin pazarlama stratejilerinin yapılandırılmasındaki rolleri büyük önem taşımaktadır. Johnson ve Kaye (2004) bloglarnn geleneksel medya ortamlarından daha inandırıcı ve daha özgür yapılandırıldığını savunmaktadır.

İlişki Pazarlaması pre-consumer (müşteri ötesi) kavramından da yola çıkarak tedarikten nihai müşteriye kadar tedarik zincirindeki tüm oyuncular ile iletişimi yönetmeyi amaçlamaktadır. E-ticaretin gelişimi ile müşteri; perakendeci, üretici, bazen de aynı zamanda tedarikçi olarak karşımıza çıkmakta ve bu sayede zincirdeki klasik yatay ilişkinin dairesel yaklaşıma doğru yöneldiği görülmektedir. Sözkonusu ilişki materyal kadar bilginin de akışını yönlendirmektedir.

Bloglar; çok sayıda bireyin -hatta işletmelerin- birbirine geçerek iletişim içinde bulunduğu önemli bir iletişim aracıdır. Bu tip platformlar, süre içinde çok yönlü kullanıcıların ve bloggerın etkin alışveriş içerisinde olmasını sağlamaktadır. Hizmet odaklı görünen bu yapı aslında ilişki pazarlama anlayışının pekişmesine teorik anlamda katkı sağlamaktadır (Vargo ve Lusch, 2004, s.3).

Birçok tanımına bakıldığında; teknik/uzman bilgi gerektirmeden, kullanıcısının istediği bilgiyi, istediği şekilde yazan bireylerin oluştur- 
duğu günlüğe benzeyen web sitesidir. Blog kelimesine karşıllk olarak, Türkçe'de "açık günlük", "ağ günlüğü", "e-günlük" gibi terimler kullanılmaktadır (Alikılıç ve Onat, 2007, s.899).

Literatüre bakıldığında farklı sınıflandırmaların görüldüğü bloglar, kullanım alanlarına göre kişisel, temasal, yayıncıların sponsor olduğu ve kurumsal bloglar şeklinde sinıflandırılırken; amaca yönelik değerlendirildiğinde kişisel, bağlantı toplayıcı, gazetecilik, siyasal ve iş için olmak üzere beş farklı gruba ayrılmaktadır (Turan, 2007, s.47) Teknolojinin sağladığı fayda ile Video (vlog), fotoğraf (photoblog), mobil araçlar (moblog) gibi farklılaştırılmış, zenginleştirilmiş blog türleri görülmektedir.

Blogger çeşidi olarak Vloggerlar (Video Bloggerlar) diğer bir ifade ile 'dijital etkileyiciler' seçili konularda aynı ilgiyi paylaşan ve benzer davranışlarda bulunan topluluklar üzerinde etkili bir role sahiptirler. Vloggerların itibarı paylaşılan içeriğin inandırıcılığı ve kullanıcının performans çıktısına göre şekillenen sübjektif bir değerdir. Vlog kültürü çok sayıda konu için gittikçe önemli ve etkili bir bilgi kaynağı oluşturmaktadır. Geleneksel medyanın yanısıra, blog ve vlogların etkileşimli bir araç olmasıyla davranışlar üzerinde ne kadar etkin olduğunu, hatta sanal dişındaki ortamlarda dahi etkisinin artarak güçlendiği gözlemlenmektedir (Lee ve Watkins, 2016, s.5753).

\section{a)Yeni medyada dijital etkileyiciler: Vlogger karakteristik özellikleri}

Yoğun bir şekilde dijital fikir liderleri olarak kullanılmaya başlanılan vloggerların seçim süreci marka iletişim stratejilerinin doğru bir şekilde ilerleyebilmesi için önemlidir. Zira marka ile özdeşleşecek olan bireyin karakteristik özellikleri marka kimliğinin oluşturulmasında kullanılan çağrışımlar ile benzer nitelikleri kapsaması sinerjik etkiyi arttıracaktır. Markalar bulundukları konuma ya da tüketicilerinin zihninde olmak istedikleri ideal yere uygun olarak stratejilerini plan, organizasyon, uygulama, kontrol ve geri besleme süreçlerini dikkate alarak her aşamasıyla kurgulamalıdırlar. Aksi takdirde, bu kadar etkili bir medya kullanımı sonrası tek bir ayağın aksamasıyla tüm iletişim çabasının çökmesi mümkündür. 
Vlogger'ın sunduğu içerik, yaratılan atmosfer, vlogger'ın karakteri, kullandığ1 dil/ifade/beden dili, nasıl bir ruh haline sahip olduğu ve fiziksel/duygusal nekadar çekici olduğu konularıyla bütünleşmelidir (Uzunoğlu ve Kip, 2014, s.595). Takipçiler seyrettikleri içeriği iletişimi yapandan bağımsız değil, bir bütün olarak değerlendirmekte ve bütünsel algısına göre genel yargıya varmaktadır.

\section{i)Vlogger'ın çekiciliği(Attractiveness)}

Bilgi kaynağının hem fiziksel hem de sosyal anlamda çekiciliği daha fazla izleyici yaratmaktadır. Vlogger'ın kişiliği ve fiziksel görünümü, izleyicisinin kendisiyle ne kadar güçlü bağ kurduğu, o kadar izleyicinin içeriği anlamasını ve benimsemesini sağlamaktadır(Lee ve Watkins, 2016, s.57545755). Görsel boyutu daha ön planda olan vloggerların fiziksel özellikleri yanında hissettirdiği sıcaklık ve etkili içeriğin bütünleşmesi sonucunda bireyler etkilenmektedir.

Öğrenme ve motivasyon temelli teorilere bakıldığında "pekiştirme" sürecin devamlılığında büyük önem taşımaktadır. Vlogger'ın fiziksel ve sosyal olarak çekici bulunması içeriğin tekrar tekrar seyredilmesine, bunun sonucunda satınalma ve sonrasında bilgi paylaşımının daha fazla motive edilmesine sebep olmaktadır (Kniffin ve Wilson, 2004, s.89; Lee ve Watkins, 2016, s. 5754-5755).

\section{ii)Vlogger'in ruh hali (Mood)}

Davranışsal bilimlerden farklı olarak vloggerların ruh hali(mod) bireyi anlamaktan daha çok yarattıkları toplulukları anlamlandırma, gruplama ve içeriği oluşturmada incelenmektedir (Mishne, 2005, s.2). Vloglardaki ruh hali sınıflandırılmasının belirgin bir gösterge olmasının ana sebebi marka konumlandırmasında kişinin ruh halinden daha çok vlogun genel ruh hali(modu) önemsenmektedir. Elbette ki tüm konumlandırma stratejileri gibi zihindeki tutulacak yerin neresi olduğuna son kararı izleyici vermektedir. İzleyicinin içeriği nasıl algıladığı vlogger'ın ruh halinden etkilenmektedir. Vloggerlar gündelik/durumsal ruh hallerinden farklı olarak vlogun genel ruh halini bir mağaza atmosferi oluşturmak gibi kurgulamakta tüm içerik o ruh halini yansıtan ifade/sunuş ile verilmektedir. 
Birçok vlogger'ın birbirinden farklı içerik hazırlama tekniği bulunmaktadır. Kullanılan dilin/ifadenin, ruh halinin vlogger tarafından ifade edilme biçimi bireylerin algılamalarını değiştirir. Hiç kuşkusuz sadece vlogger'ın ruh hali değil, izleyicilerin ruh halinin de mesajın iletilmesinde etkisi bulunmaktadır. Bu durum çoğunlukla dezavantaj olarak görülse de avantaja dönüştürülebilmesi en kolay yöntemdir. Dijital etkileyicilerin(vlogger) fikrini direkt iletebilme yetkisi vardır. İçeriğin interaktif bir şekilde tüm taraflar açısından kolayda anlaşılması negatif/pozitif duyguların iletilmesi süreçte değil, anlık olarak tüketme şansı tanımaktadır. Böylelikle istenilmeyen bir algılamanın anlık olarak öne geçilmesi sağlanarak içerik yönetimi kolaylaşır. Vloggerlar takipçileri sayesinde oluşturdukları toplulukları kolayca yönetebilme yetisine sahiptirler. Vlog içerikleri takipçilerden gelen güven ve destek ile yapılandırılarak takipçilerin yorum sıklığına göre de şekillendirmektedir.Vloggerın ruh hali aldığı yorumlara göre pozitif veya negatif değişebilir. Dolayısıyla interaktif olan bu mecrada içeriğe yansıyabilecek her olumsuzluğun kontol edilmesi gerekmektedir. Vloglarda aracı bir başka iletişim mecrası olmadığından ve direkt bir iletişim söz konusu olduğundan vloggerın ruh hali ve yarattığ1 topluluğuna yansıma şekli markalar açısından dikkate alınması şart olan bir husustur (Veer, 2013, s.147).

\section{b.Vlogger'ın Bilgi Birikimi Tipi:}

Günümüzde Vloggerlar kendi ilgi alanlarındaki bilgiye açık, hatta bu bilgiyi detaylıca araştırarak hakkında konuşmacı olma rolünü üstlenen, etkileyici ve değer gören toplumsal bireylerdir. Dijital dünyanın güçlü silahı olarak nitelendirilen Vloggerlar, markaları yapılandırabilen, yok edebilen, politik iktadara yön verebilen, haberlerden hikayeler yaratan potansiyele sahip güçtedirler. Var olan bilgi ve daha fazlasına ulaşabilir olmaları sebebiyle korkutucu kimliğe sahiptirler (Hsu ve Tsou, 2011, s.511). Vloglar, nihai kullanıcılara iletilen ve yayılan bilginin, vloggerların yorumları eklenerek ne denli değişebildiğini gösteren bir örnektir.

Vloggerlar önce bilgiyi filtreler, daha sonra kendi fikirlerini ekleyerek paylaşırlar, dolayısıyla doğrudan bireysel aktarımları okuyucu ve dinleyicileri nezdinde çok etkilidir (Sanchez-Villar vd., 2017, s.104). 
Vloggerlar'ın teknik/konusunda uzman olarak ünlenmiş veya deneyimlerinden kaynaklanan bilgiye sahip, bizzat kendisi tüketici olan bireysel vlog tiplerinden bahsedilmektedir. Ürün veya istek/ihtiyaç ile ilgili bilgi arayışı içerisinde olan bireyler çoğunlukla kolayda olmasının avantajı ile interneti kullanmaktadırlar. Bilgi kaynağından beklenilen özellikler arasında profesyonellik, içeriğin geçerliliği, doğruluğu ve kaynak sağlayıcının itibarı bulunmaktadır (Chen-Hsun vd.2015, s.346).

Vloggerlar'ın bilgi birikim kaynakların değerlendirirken iki farklı türden bahsetmek gerekir:

- Teknik/uzmanlık kaynaklı bilgi birikimi: Uzmanlık kaynaklı bilgi kaynağı insan sermayesidir. Eğitim amacı daha ön planda olan bu tip vloglar teknik bilgiyi vermeyi amaçlamaktadır. Seçili konularda kitlelerin farkındalığını arttırmak ve bu tip blogları bilişsel öğrenim aracı olarak değerlendirmek mümkündür. Bu bilgi birikimini sunan vloglar kişisel duygu/düşüncelerini yayan platformlar yerine bilişsel öğrenim aracı olma içgüdüsündedirler.(Yueh vd., 2013, s.239-240). Dezavantajlı tarafı öğretmenöğrenci ilişkisinde olup tek yönlü iletişim sözkonusudur.

- Deneyim kaynaklı bilgi birikimi: Çift yönlü etkileşim söz konusudur. Bu tip vloggerlar'ın sosyalleşme, topluluk hareketi yapma ihtiyacı bulunmaktadır (Doyle vd., 2012, s.838). Konu hakkında ilgilenim düzeyi yüksek olan vlogger'ın kendisi edindiği/deneyimlediği tecrübe üzerinden içeriği oluşturmaktadır (Berryman ve Kavka, 2017, s.318).

Son dönemde blog/vlog sayılarının artışıla çeşitlilik kadar bilgi kirliliği de oluşmuş, kolayda olan sosyal platform üzerinden ünlü/ünsüz fikir liderleri türemiştir. Bireyler kendi ihtiyaç ve isteklerini karşılayacak bilgi kaynaklarına başvururken farklı algılar içerisinde hareket etmektedirler. Kimi zaman uzman görüşü ve teknik bilgi ön plandayken; -teorik kalır- endişesi ve- uygulayan daha iyi bilir-felsefesiyle yaklaşan izleyicilerin sayısı da her geçen gün artmaktadır.

\section{c. Vlogger'ın İtibarı kavramı}

Katz ve Lazerfeld'in (1955) İki Aşamalı Akış modeline esasen bilgi aktarılması ve tutumların değsşmesinde kişilerarası iliş,kilerin daha geniş bir 
etkiye sahip olduğu ve kitle iletişim araçlarının doğrudan etkisinin sınırlı oldugunu saptanmıştır (Erdoğan vd., 2005, s.17-18). İki Aşamalı Akış modelinde araya Fikir Liderleri girmekte ve bilgi, etki akışı içindeyken Fikir liderinden geçerek gerçekleşmektedir (Yaylagül, 2010, s.56-57). Fikir lideri etkin rol üstlenerek, bilgiyi etkili olduğu grubun dünya görüs,üne göre biçimlendiren güvenilir bir kaynaktır. Fikir lideri, iletişimde önemli bir rol üstlenerek, yüksek düzeyde toplumsal niteliklerinin yanında diğerleri üzerinde etkili olduklarının bilincinde kaynak ve rehber rolü üstlenen grup üyesi olarak düşünuilebilir (McQuail ve Windahl,2010, s.85).

Dijital dünyada günümüz bloggerları esasen geleneksel anlamda kabul görmüş fikir liderleri niteliğinde hareket etmekte ve konumları ile ilgili iletişim içeriğini araştırıp, okuyup, seyredip özümsedikten sonra iletmektedirler (Hansen vd, 2011, s.23). Popüler düşünce fikir liderliğini yüksek statüyle, prestijle eşleştirmiştir. Katz (1957, s.73) fikir liderlerini üç ortak karakteristik ve davranışsal özelliğine göre gruplamaktadır; Belirgin değerlerin kişiselleştirilmesi (kimdir), yetkinlik- yeterlik ( ne bilir) ve stratejik toplumsal konumu ( kim tanır). İlk boyut fikir liderinin kişisel özellikleri ve değerleri ile ilişkilidir, ikinci boyut olan yetkinlik-yeterlik, belirgin bir konuda önderin uzmanlık derecesini tartışır, üçüncü boyut olan toplumsal konumu ise, iletişim ağının gücünü ve kapasitesini sorgulamaktadır. Fikir liderliği nekadar çok sayıda kişi tarafından kabul ediliyorsa, o kadar çok uzmanlığı ve itibarı meşrulaşmaktadır.

Vloggerları dijital dünyanın fikir liderleri olmaları varsayımından yola çıkarsak, herbir blogger kendi bireysel markalarını yönetme ve bu markaların güvenirliliğini yükseltebilmek için uğraşmaktadır. Güçlü bir marka; ayırt edilebilen, tercih oluşturma sebebi ve itibarlı olma yetisine sahip olması ile ayrışmaktadır.

İtibar disiplinler arası tartışılan bir kavramdır. Pazarlamadan, sosyal psikolijiye, ekonomiden karar bilimleri ve iletişim bilimlerine konu olmuş olan bu kavram, Adam Smith'in (1978) bakış açısıyla 'sürdürülebilir alışverişi sağlayıcı bir disiplin' olması yönüyle açıklanmaktadır. İtibar, genel olarak bireyler gözünde ya da belleğinde sahip olduğunuz öngörü, nitelikler ya da karakterler bütünü olarak tanımlanmaktadır. Ortak bir kullanımla itibar bir kişiye, bir endüstriye bir diğeri tarafından atfedilen nitelik, karakteristiklerin bütünüdür (Malaga, 2001, s.404). Türk dil kurumu sözlüğü itibarı, değerli görülme, saygın bulma, güvenilir olma ile 
eşleştirmekte ve kısaca; saygınlık ve prestij olarak tanımlanmaktadır (www.tdk.gov.tr). İtibar, bir bireyin, işletmenin ve/veya bir markanın genelde görünür olan ve insanlar tarafından değerlendirilen toplam saygınlık değeri ve karakteridir (Chaudhuri, 2002, s.34).

Nihai kullanıcılar için önemli olan, 'işletmenin ne olduğu veya bireyin kim olduğundan öte 'işletmeye veya bireye yönelik inanışları biçimlendiren' algıdır (Tosun, 2014, s.184). İtibar; imaj, iyi niyet ve kimlik gibi tümsel oluşmuş algının bütünüdür.

Sosyal medya sürekli paylaşımın gerçekleşebileceği bir çok farklı platform sunmaktadır; forumlar, bloglar, sosyal ağlar, email vb. Bu ortamlarda paylaşılan ve aktarılan fikir, görüş, tecrübeler bir nevi elektronik ağızdan ağıza iletişimi yaygınlaştırmaktadır (Filieri ve Mcleay, 2014, s.45). Nihai kullanıcılar bu paylaşımları işletmelerin mesajlarından daha güvenilir ve itibarlı olarak değerlendirmektedir. Paylaşımların bireysel tecrübelere dayalı oluşu daha itibarlı olacağı varsayımını öne çıkarmaktadır (Buttle,1998, s.243-245).

Geleneksel yaklaşımlarda, fikir liderleri yüz yüze iletişim ile sınırlı iken, dijital etkileyiciler çoklu sosyal platformlar aracılığı ile daha fazla kişiye ulaşabilmekte ve daha etkili iletişim kurabilmektedir. Buradaki esas kaygı ise, Vlogger'ın yaydığı bilginin itibarlı olup olmamasına yöneliktir. İtibar dokunulmaz bir değer olarak tanımlanırken, bir markanın tüm faaliyetlerini, sundukları ürün ve hizmetleri hakkında beklentileri, oluşabilecek tepkileri, gelecek paylaşımları ile ilgili öngörüleri ve geçmişin yansımalarını içermektedir. Markaların görünür ve bilinir olmaları yüksek itibar ile ilişkilendirilmektedir (Chaudhuri,2002, s.35-38; Milewicz ve Herbig, 1994, s.41). Marka itibarı geriye dönük kazançla beraber ileriye dönük karlılığı nitelemektedir (Dahlen vd., 2009, s.156).

Çoğu vlogdan yayılan bilgi analog uyarıcı olarak nitelendirildiğinde, bu bilginin algılanan kalitesinin yükselmesi o bloğun daha fazla sadık okuyucu tarafindan takip edilmesini ve dolayısıyla pozitif bir imaja sahip olmasını tetiklemektedir (Sanchez-Villar vd., 2017, s.104). Sanal etkileşim içinde, aktarılan bilginin kalitesi gönderenin (aktarıcı) güvenirliliğini sağlayıcı en önemli gösterge olarak kabul edilmektedir (Filieri,2015, s. 4647; Liljander vd., 2015, s.615). Kişisel gereklilik ve bilgi sisteminin sağladığı faydaların dışında, kullanıcıların her hangi bir sistemden (vlog veya bloglardan bahsedilmekte) edindiği 'bilgi' bireysel performansını 
pozitif etkiliyorsa bilginin doğruluğu kanıksanmıştır. Doğru bilgi sağladığı inanılan bir blog itibarlı ve güvenilir olarak bireysel kullanıcı tecrübesine kayıt edilir. Tekrardan ihtiyaç duyulduğunda risk almamak adına memnun olunan kaynağa başvurulması gerçeği kaçınılmazdır (Zaichkowsky,1985, s.348; Zehrer vd., 2011, s.108). Bu baglamda bloglar, gözetlenen kullanıcılar olgusunun pekişmesine neden olurken bilgi toplamanın, bilgi dağıtmanın ve etkileyici gücün temel dinamiklerine hizmet eden bir iletişim aracı rolünü doğru kullanmaktadır (Peltekoglu ve Akbayır, 2010, s.5).

Özetle; Vlogların sanal yaratıciları olan vloggerlar, etkin topluluk oluşturmada ve sayfalarının içeriğinin yüksek kullanıcılar tarafından takip edilmesinde 'itibar' kavramı lokomotif bir görev üstlenmektedir. Vloggerların karakteristik özellikleri ve video çekimlerindeki ruh halleri direk veya dolaylı olarak takipçiler üzerinde etki oluşturmaktadır. Bu etki markalar düzeyinde değerlendirildiğinde, kullanıcıların ürünü beğenip ve vloggerı itibarlı bularak güvenip önerilen ürün/leri satınalma veya satın almama ile ilişkilendirildiğinden önem arz etmektedir.

\section{Yöntem}

\section{a. Araștırmanın Modeli}

Çalışmanın ana sorusu vloggerların karakteristik özelliklerinden ilgi çekicilik ve vlogger'ın sergilediği ruh halinin vlogger itibarı üzerine etkisinin araştırmaktır. İtibar oluşumunda vlogger'ın bilgi birikiminin kaynağı da literatüre bakıldığında satınalma ve satınalma sonrası davranışlarını etkilediği görülmektedir.

Literatürden elde edilen bilgiler ışığında oluşturulan araştırma modelinde amaç, Vlogger'ın bilgi türünün, modunun ve çekiciliğinin itibarına olan etkisini bulmaktır. Bu amaç doğrultusunda üç hipotez test edilmiştir. Hipotezle sırasıyla aşağıdaki gibi yapılandırılmıştır.

H1: Vlogger'ın çekiciliği itibarını etkiler.

H2: Vlogger'ın ruh hali itibarını etkiler.

H3: Vlogger'ın bilgi birikimi tipi itibarını etkiler. 


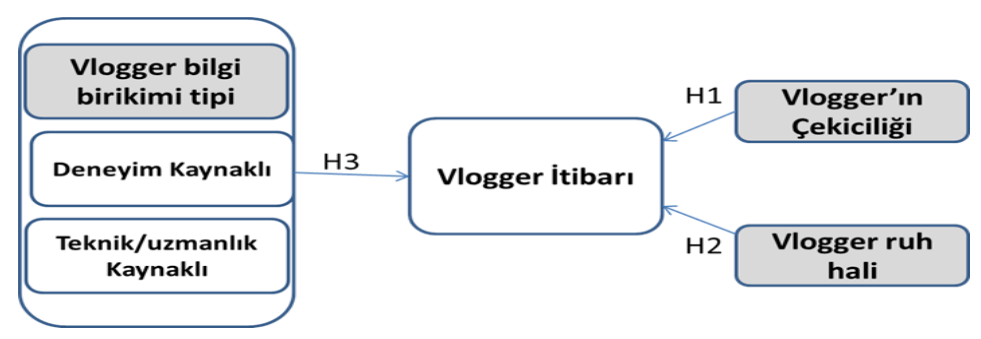

Şekil 1. Araştırma Modeli

\section{b. Örneklem}

Araştırma kapsamında kullanılan anket 250 kişiye uygulanmıştır. Veri analizleri öncesinde araştırmaya katılanların ankete verdikleri cevaplar incelenmiş her bir boyutu ölçen sorulardan en az \%5'ini boş birakan deneklerin anketleri analize alınmamıştır. Ayrıca katılımcılar daha öne bir Vlogger takip ediyor olma ön şartına göre seçilmiştir. Tüm bu koşullar altında toplam 300 kişiye uygulanan anket sonuçlarından 224 tanesi araştırma modelinin test edilmesinde kullanılmıştır. Katılımcıların cinsiyet, Eğitim Durumu, Gelir Düzeyi ve Yaş demografik özellikleri Tablo 1'de verilmiştir.

Tablo 1. Demografik değişkenlerin dağılımı

\begin{tabular}{|c|c|c|}
\hline & $\mathbf{N}$ & $\%$ \\
\hline \multicolumn{3}{|l|}{ Cinsiyet } \\
\hline Kadın & 113 & 50,4 \\
\hline Erkek & 111 & 49,6 \\
\hline \multicolumn{3}{|l|}{ Eğitim Durumu } \\
\hline Lise & 27 & 12,1 \\
\hline Üniversite & 152 & 67,9 \\
\hline Yüksek Lisans & 38 & 17,0 \\
\hline Doktora & 7 & 3,1 \\
\hline \multicolumn{3}{|l|}{ Gelir Düzeyi } \\
\hline 500 TL' kadar & 70 & 31,3 \\
\hline 500 TL- 1000 TL aras 1 & 43 & 19,2 \\
\hline 1. $000 \mathrm{TL}-3000 \mathrm{TL}$ aras 1 & 37 & 16,5 \\
\hline 3. $000 \mathrm{TL}-5000 \mathrm{TL}$ aras 1 & 38 & 17,0 \\
\hline 5.000 TL ve üzeri & 36 & 16,1 \\
\hline \multicolumn{3}{|l|}{ Yaş } \\
\hline Ortalama & \multicolumn{2}{|c|}{24,86} \\
\hline Standart Sapma & \multicolumn{2}{|c|}{2,96} \\
\hline
\end{tabular}


Sonuçta analizler 18-32 yaş aralığında 113 Kadın $(\% 50,4) 111$ Erkek $(\% 49,6)$ olmak üzere toplam 224 kişiden elde edilen veriler 1şığında yapılmıştır. Araştırmaya katılanların yaş ortalaması 24,86 standart sapması 2,96'dır. Katılımcıların \%67,9'u Üniversite mezunudur.

\section{c. Ölçüm Aracı}

Araştırma modelinde yer alan hipotezleri test etmek amaciyla her bir değişken için literatürden ölçekler bulunmuştur. Tüm anket sorularının ölçümünde 5'li Likert ölçek 1=Hiç Katılmıyorum 5=Tamamen Katılıyorum aralığında kullanılmıştır. Anket iki bölümden oluşmaktadır. Birinci bölümde demografik sorular ile "Herhangi bir Vlogger takip ediyor musunuz?" sorusu yer almaktadır. Bu soruya "Hayır" cevabı veren denekler araştırmaya alınmamıştır. İkinci bölümde geçerliliği ve güvenirliliği test edilmiş ölçeklerden oluşan Bilgi türü, Çekicilik, Mod ve İtibar soruları sorulmuştur.

Tablo 2. Araştırmada Kullanılan Ölçekler

\begin{tabular}{|c|c|c|}
\hline Boyut & Ölçek & Kaynak \\
\hline \multirow{21}{*}{$\begin{array}{l}\text { Vlogger } \\
\text { Bilgi Biri- } \\
\text { kimi Tipi }\end{array}$} & Teknik/Uzmanlk Bilgi Birikimi & \multirow{21}{*}{$\begin{array}{l}\text { Doyle vd., } \\
2012\end{array}$} \\
\hline & Vlogger alanında uzmandır & \\
\hline & Vlogger bir veya fazla üniversite bitirmiştir & \\
\hline & Vlogger alanında uzman eğitim almıştır & \\
\hline & Vlogger ödüller kazanmıştır & \\
\hline & Vlogger konuyla ilgili kitap veya akademik yazılar yazmıştır & \\
\hline & Vlogger konuyla ilgili eğitim vermektedir & \\
\hline & Vlogger sözkonusu sektörde çalışmaktadır & \\
\hline & Vlogger konuyla ilgili güncel medyada yazmaktadır & \\
\hline & Deneyim Kaynakl Bilgi Birikimi & \\
\hline & Vlogger'ım engin bir tecrübeye sahiptir & \\
\hline & Vlogger'ım alanında geniş kapsamlı tecrübeye sahiptir & \\
\hline & Vlogger'ım başkalarının sağlayamadığı bilgileri sağlamaktadır & \\
\hline & Vlogger konuya yoğun şekilde kendini adamıştır & \\
\hline & Vlogger konuyla ilgili isteklidir & \\
\hline & Vlogger konusunda önemli bir konumdadır. & \\
\hline & Vlogger konuyla ilgili çalışmalarına kenetlenmiştir & \\
\hline & Vlogger alanındaki gelişmelerle ilgilidir & \\
\hline & Vlogger konuyla ilgili çalışmaya çok zaman harcar & \\
\hline & Vlogger konunun alışılmışın dışındaki yönlerini de bilir & \\
\hline & Vlogger doğru terminolojiyi(kavramları/ifadeleri vb.) kullanır & \\
\hline
\end{tabular}




\begin{tabular}{|c|c|c|}
\hline \multirow{10}{*}{$\begin{array}{c}\text { Vlogger Ruh } \\
\text { Hali }\end{array}$} & Mutlu & \multirow{10}{*}{ Mishne, 2005} \\
\hline & Heyecanlı & \\
\hline & Rahat & \\
\hline & Üzgün & \\
\hline & Sikıcl & \\
\hline & Hayal kırıklığ & \\
\hline & Şaşkın & \\
\hline & Sinirli & \\
\hline & Stresli & \\
\hline & Kizgın & \\
\hline \multirow{5}{*}{$\begin{array}{l}\text { Vlogger Çe- } \\
\text { kiciliği }\end{array}$} & Güzel & \multirow{5}{*}{$\begin{array}{c}\text { Fiore vd., } \\
2008 \\
\text { Kniffin ve } \\
\text { Wilson, 2004 } \\
\text { Biel ve Ga- } \\
\text { tica-Perez, } \\
2012 \\
\end{array}$} \\
\hline & Sevimli & \\
\hline & Arkadaş canlısı & \\
\hline & Zeki & \\
\hline & Sikıci & \\
\hline \multirow{3}{*}{$\begin{array}{l}\text { Vlogger } \\
\text { İtibarı }\end{array}$} & Vlogger'lar dürüstlükleriyle tanınırlar & \multirow{3}{*}{$\begin{array}{c}\text { Lim vd., } 2006 \\
\text { Hsu ve Lim, } \\
2008\end{array}$} \\
\hline & Vlogger'lar internette iyi bir üne sahiptirler & \\
\hline & Birçok vlog kullanıcısı vlogger tanımaktadır & \\
\hline
\end{tabular}

\section{d. Analiz}

Araştırmanın istatistiksel analizlerine ilk olarak "İtibar" ve "Bilgi Birikimi Tipi" ölçeklerine betimleyici faktör ve güvenilirlik analizleriyle başlanmış; bu analizler sonucunda ölçeklerin alt boyutları saptanmıştır.

\section{Faktör Analizi}

\section{İtibar Faktör Analizi}

İtibar alt boyutlarını tespit etmek amacıyla betimleyici faktör analizi yapılmıştır. Veri setinin faktör analizine uygunluğunun test edilmesi için, Kaiser-Meyer-Olkin (KMO) örneklem yeterliliği testi ve Bartlett testi uygulanmış, KMO değeri 0,50'nin üzerinde olduğu ve Bartlett testi de 0,05 önem derecesinde anlamlı olduğundan (Sharma, 1996) veri seti faktör analizine uygun bulunmuştur. (KMO=0,637, $\chi^{2}$ Bartlett test (3)=158,644, $\mathrm{p}=0,000$ ). Temel bileşenler yöntemi ve Varimax döndürme yöntemi kullanılarak sorular analiz edilmiştir. Yapılan faktör analizinde özdeğerleri 1 ve üzerinde olan bir faktör ortaya çıkmıştır. Faktörün içsel 
tutarlığını hesaplanmasında Cronbach $\alpha$ değerleri kullanılmıştır. 0 ile 1 arasında değişen $\alpha$ katsayısı o faktörün içsel tutarlılığını (güvenilirliğini) göstermektedir. Belirlenen her faktör için $\alpha$ katsayısının 0,70 üzerinde olması ölçeklerin güvenilir olduğunu göstermektedir. Yapılan güvenilirlik testi sonucunda Cronbach $\alpha$ değeri 0,729 çıkmıştır.

Tablo 3. İtibar Ölçeği Betimleyici Faktör Analizi Sonucu

\begin{tabular}{lccc}
\multicolumn{1}{c}{ Faktör Adı } & $\begin{array}{c}\text { Faktör } \\
\text { Yükü }\end{array}$ & $\begin{array}{c}\text { Açıklanan } \\
\text { varyans (\%) }\end{array}$ & Güvenilirlik \\
\hline $\begin{array}{l}\text { İtibar } \\
\text { Vlogger'lar internette iyi bir }\end{array}$ & 0,875 & & \\
$\begin{array}{l}\text { üne sahiptirler } \\
\begin{array}{l}\text { Birçok vlog kullanıcısı vlogger } \\
\text { tanımaktadır. }\end{array}\end{array}$ & 0,784 & 65,68 & 0,729 \\
$\begin{array}{l}\text { Vlogger'lar } \\
\text { dürüstlükleriyle tanınırlar. }\end{array}$ & 0,768 & & \\
\hline
\end{tabular}

\section{Bilgi Birikimi Tipi Faktör Analizi}

Bilgi birikimi tipi alt boyutların tespit etmek amaciyla betimleyici faktör analizi yapılmıştır. Veri setinin faktör analizine uygunluğunun test edilmesi için, Kaiser-Meyer-Olkin (KMO) örneklem yeterliliği testi ve Bartlett testi uygulanmış, KMO değeri 0,50'nin üzerinde olduğu ve Bartlett testi de 0,05 önem derecesinde anlamlı olduğundan (Sharma, 1996) veri seti faktör analizine uygun bulunmuştur. (KMO $=0,923, \chi^{2}$ Bartlett test $(105)=1984,838, \mathrm{p}=0,000)$. Temel bileşenler yöntemi ve Varimax döndürme yöntemi kullanılarak sorular analiz edilmiştir. Yapılan faktör analizinde özdeğerleri 1 ve üzerinde olan 2 faktör ortaya çıarken, birden fazla faktör altında yüksek faktör ağırlığı olan sorular analizden çıkarılmıştır. Sonuç olarak 15 sorudan oluşan iki faktör elde edilmiştir. Toplam açıklanan varyans (sapma) \%61,30 olarak bulunmuştur. Faktörler sırasıyla; "Teknik/uzmanlık Kaynaklı Bilgi Birikimi" ve "Deneyim Kaynaklı Bilgi Birikimi" olarak adlandırılmıştır. Güvenilirlik testi sonucunda Cronbach $\alpha$ değerleri sirasıyla 0,909 ve 0,886 bulunmuştur. 
Yapılan faktör analizleri sonucunda araştırma modelinde yer alan bilgi türü alt boyutları olan Teknik/uzmanlık ve Deneyim Kaynaklı Bilgi Birikim, Vlogger'ın Çekiciliği ve Vlogger'ın Ruh hali soruları araştırma

Yapılan faktör analizleri sonucunda araştırma modelinde yer alan bilgi türü alt boyutları olan Teknik/uzmanlık ve Deneyim Kaynaklı Bilgi Birikim, Vlogger'ın Çekiciliği ve Vlogger'ın Ruh hali soruları araştırma modelini test etmek amacıyla çoklu doğrusal regresyon analizinde bağımsız değişkenler olarak kullanılmıştır. Bağımlı değişkenimiz olan İtibar değişkeni yapılan faktör analizi sonucunda tek boyut olarak bulunmuş çoklu doğrusal regresyon analizimizde bağımsız değişken olarak kullanılmıştır.

Yapılan faktör analizleri sonucunda araştırma modelinde yer alan bilgi türü alt boyutları olan Teknik/uzmanlık ve Deneyim Kaynaklı Bilgi Birikim, Vlogger'ın Çekiciliği ve Vlogger'ın Ruh hali soruları araştırmamodelini test etmek amacıyla çoklu doğrusal regresyon analizinde bağımsız değişkenler olarak kullanılmıştır. Bağımlı değişkenimiz olan İtibar değişkeni yapılan faktör analizi sonucunda tek boyut olarak bulunmuş çoklu doğrusal regresyon analizimizde bağımsız değişken olarak kullanılmıştır.

Tablo 4. Vlogger Bilgi Birikimi Türü Ölçeği Betimleyici Faktör Analizi Sonucu

\begin{tabular}{|c|c|c|c|}
\hline Faktör Adı & $\begin{array}{l}\text { Faktör } \\
\text { Yükü }\end{array}$ & $\begin{array}{c}\text { Açıkla- } \\
\text { nan } \\
\text { Sapma } \\
(\%)\end{array}$ & Güvenilirlik \\
\hline \multicolumn{4}{|l|}{ Deneyim Kaynaklı Bilgi Birikimi } \\
\hline Vlogger konuyla ilgili isteklidir. & 0,814 & \multirow{9}{*}{33,80} & \multirow{9}{*}{0,909} \\
\hline Vlogger alanındaki gelişmelerle ilgilidir. & 0,784 & & \\
\hline Vlogger konuyla ilgili çalışmalarına kenetlenmiştir. & 0,772 & & \\
\hline Vlogger konuya yoğun şekilde kendini adamıştır. & 0,770 & & \\
\hline $\begin{array}{l}\text { Vlogger konunun alışılmışın dışındaki yönlerini de bi- } \\
\text { lir. }\end{array}$ & 0,708 & & \\
\hline Vlogger konuyla ilgili çalışmaya çok zaman harcar. & 0,677 & & \\
\hline $\begin{array}{l}\text { Vlogger doğru terminolojiyi(kavramları/ifadeleri vb.) } \\
\text { kullanır. }\end{array}$ & 0,672 & & \\
\hline Vlogger alanında geniş kapsamlı tecrübeye sahiptir. & 0,668 & & \\
\hline Vlogger konusunda önemli bir konumdadır. & 0,590 & & \\
\hline
\end{tabular}




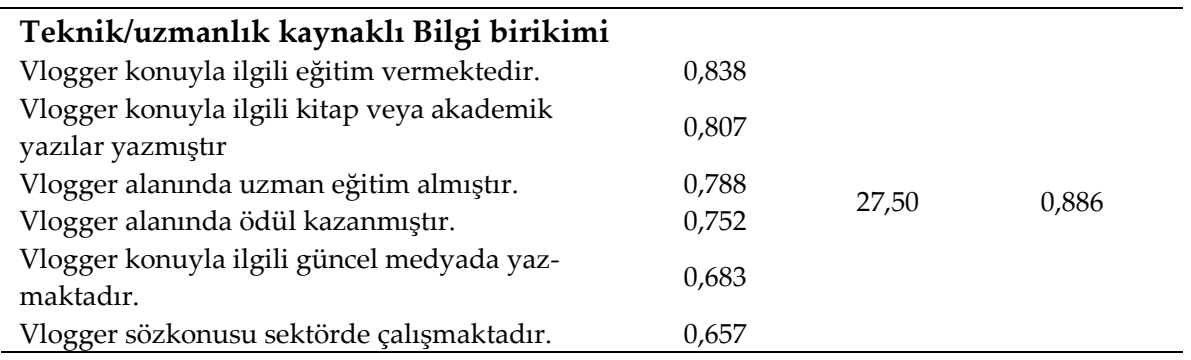

Yapılan faktör analizleri sonucunda araştırma modelinde yer alan bilgi türü alt boyutları olan Teknik/uzmanlık ve Deneyim Kaynaklı Bilgi Birikim, Vlogger'ın Çekiciliği ve Vlogger'ın Ruh hali soruları araştırma modelini test etmek amacıyla çoklu doğrusal regresyon analizinde bağımsız değişkenler olarak kullanılmıştır. Bağımlı değişkenimiz olan İtibar değişkeni yapılan faktör analizi sonucunda tek boyut olarak bulunmuş çoklu doğrusal regresyon analizimizde bağımsız değişken olarak kullanılmıştır.

\section{Çoklu Doğrusal Regresyon Analizi}

Vlogger'ın Çekiciliği, Ruh Hali, Teknik/Uzmanlık Kaynaklı ve Deneyim Kaynaklı Bilgi Birikimi kavramlarının İtibarı ne kadar etkilediği yapılan çoklu doğrusal regresyon analizi sonucunda bulunmuştur. Ruh hali sorularından Mutlu, Çekicilik sorularından Arkadaş Canlısı sorularının İtibarı etkilediği ( $R=0,823$; $R 2=0,678$ F (3)=126,344; $p=0,000)$ bulunmuştur. Deneyim Kaynaklı Bilgi Birikimi kavramı İtibarı etkileyen en yüksek $\chi^{2}$ değerine sahiptir.

Tablo 5. Çoklu Doğrusal Regresyon Analizi Sonucu

\section{Bağımlı değişken: İtibar}

\begin{tabular}{lccc}
\hline Bağımsız değişkenler: & Beta & t değeri & p değeri \\
Deneyim Kaynaklı Bilgi Birikimi & 0,504 & 9,657 & 0,000 \\
Mutlu & 0,222 & 4,130 & 0,000 \\
Arkadaş canlısı & 0,208 & 3,708 & 0,000 \\
R=0,728; $\mathrm{R}^{2}=0,530 ;$ F değeri=77,482; p değeri=0,000 & & \\
\hline
\end{tabular}


Tablo 5'de görüldüğü gibi En çok açıklayıcılık Deneyim Kaynaklı Bilgi $\beta=0,504$ 'dür onu takip eden Mutlu $\beta=0,222$ ve Arkadaş Canlısı $\beta=0,208$ değerleri ile sırasıyla İtibarı etkilemektedir.

\section{Sonuç ve Öneriler}

Teknolojinin kullanımı her nekadar iletişimi kolaylaştırsa da soyutdokunulamaz- hissi tercihleri geleneksel yöntemlere yöneltmektedir. Topluluk oluşturma, bir gruba ait olma, kollektif hareket edebilme duygusu geleneksel/açıklayıcı modellerin yanında modern tüketici davranış modellerinde de yeralmaktadır. Blog çalışmadaki formatıyla vlogbirlikte olma, bir grupla hareket etme, benzer veya karşı duyguların tartışıldığ platformaların yaratılmasına yardımcı olmaktadır. Vlogların görüntü, interaktivite özellikleri sayesinde dokunulamaz, görülemez dezavantajı büyük ölçüde azaltmaktadır.

Vloggerlar gerek fiziksel gerekse ruhsal olarak yarattıkları ortam sayesinde bireylerin ilgisini çekmekte, marka-birey-vlogger üçlemesiyle özdeşip ortak bir iletişim dili yakalamaya yardımcı olmaktadır. Kaldı ki, izleyiciler itibarına güvendikleri vloggerları takip etmeye devam etme eğilimindedirler.

Ruh hali olarak mutlu; çekicilik olarak arkadaş canlısı yaklaşımın itibar algısını etkilediği görüldüğünde marka iletişiminde mutluluk, pozitif duygular içeren yaklaşımın yanında arkadaş gibi kişiliklerin kullanılması vlog izleyicisinin talebini arttıracaktır. Dahası bu tip vloggerların önerdiği ürün ve tavsiyeler izleyiciler tarafından itibar edilecektir.

Literatürdeki bazı çalışmaların aksine deneyimden kaynaklı bilgi birikimine sahip vloggerlar daha çok tercih edilmekte ve bu tip bilgi birikimine sahip vlogger'ın itibarı üzerinde daha yüksek etki bulunmaktadır. Vlogger tercihinde markalar iletişim içeriklerine uygun olarak daha çok deneyim kaynaklı bilgi birikimine sahip, mutlu ifade edişe sahip, arkadaş canlısı bir yaklaşımda bulunanları tercih etmelidirler. Marka itibarı vlogger'ın itibarı iletişim dilindeki bahsedilen sıcaklığı yaratmakla özdeşleşmektedir.

Çalışmanın orjinalliği vloggerlar üzerine yapılan henüz az sayıda akademik çalışma olmasıdır. Gelecekteki çalışmalara ışık tutmak amacıyla 
ürün sınıflandırması ayrıştırmasına gidilmesi tavsiye edilmektedir. Vlogger markasının yönetim sürecini kapsayan tüm kavramlar(marka kişiliği, marka çağrışımları gibi) gelecekteki çalışmaların konusu arasındadır. Ayrıca, marka iletişimi çabalarında vlog kullanımını amaçlayan firmaların vloggerın karakteristik özellikleri, ruh hali ve bilgi birikimi tipleri konusunda ayrıştırıcı seçimler yapması çoğunlukla itibarı doğru yönetebilmek adına mutlu, pozitif ve sıcak diyaloglardan oluşan içerik yönetimini benimsemesi tavsiye edilmektedir. 
EXTENDED ABSTRACT

\title{
Digital Influencers in New Media as a Marketing Communication Tool: A Research About The Effects of Vloggers' Characteristics and Types of Knowledge on Vlogger' Reputation \\ *
}

\author{
D. Zeynep Bayazıt - Beril Durmuş - Figen Yıldırım
}

İstanbul Commerce University - Marmara University

The development of technology, one of the major macroeconomic impact of globalization, makes it easier to share information with different contents in every medium. Different media tools emerge in the extension of the information flow provided by technology. Social media allows marketers with an wide set of media tools that enable them to reach targets directly. These platforms allows for creative and innovative social media marketing strategies.

The blogs that appeared as blogs in the past have now been replaced by vlogs that appeal to our multiple senses at the same time. The spread and popularity of the vlogs vary according to the content structure and the characteristics of the creator (vlogger). Vloggers are favored according to their brand identity essence like the same with brands. Vloggers' recommendations are adopted according to their own identity characteristics rather than their contents.Vloggers tend to view end-users as clients instead of valuable resources for spreading the information. In order to lead effective social interaction, an authoritative or experience based knowledged vloggers should generate sustainable content in order to increase trustworthiness and for reinforced communication.

Vloggers, in other words, digital influencers have an effective role on communities that share the same interest in similar issues and behave in similar ways. Vloggers' reputation is a subjective value that is shaped according to the credibility of the shared content and the satisfaction level of users. 
Community creation, belonging to a group, the sense of collective mobility, as well as traditional / explanatory models, are also included in modern consumer behavior models. The vblog helps the idea of creating platforms in which similar or counter-feelings are discussed.

Vlogger's content, the atmosphere created, the character of the vlogger, the language / expression / body language that it uses, the kind of mood it has, and how physically / emotionally attractive it should be, should be integrated. The attractiveness of Vloggers, their mood, the type of knowledge change customers' interest in the content and changes in their intention to purchase. Based on the assumption that the Vloggers are the leaders of the digital world, each blogger strives to manage his/her own individual brands and it increases the reliability of these brands.

In summary; Vloggers, who are the virtual creators of Vlogs, play a key role in creating an effective community and pursuing customers to follow the content.

The characteristics of the Vloggers and the moods of the video shootings directly or indirectly have an impact on the followers. When this effect is evaluated by brands, the relationship between the liking of the product and the reputation of the vlogger should be noticed. The tendency to buy the products recommended by Vlogger is closely related the trust and reputation of vlogger.

Just as the atmosphere of the store, vloggers' mood,characteristics and credibility affect the quality of the audience experience and purchase intention with the perception consisting of five senses. The customer's perception process is also the total power of the vlog's atmosphere created by addressing all senses.

The main question of the study is to investigate the effect of the vloggers' attractiveness and mood on the vlogger's reputation. In contrast to some studies in the literature, experience(engagement) based knowledged vloggers are more preferred and have a higher impact on the reputation of the vlogger with such knowledge. While it is expected that vlogs will be managed by people with technical / expert (authoritative) knowledge, it seems to be shifted towards experience based knowledged vloggers who are felt to be more realistic in the recent period. This study implies that the vblog can be a meaningful marketing communication platform and the 
vloggers'mood and vloggers characteristics can be a significant medium in having/sharing the knowledge for increasing vloggers' reputation.

The questionnaire was applied to 224 vlog audiences. According to the research findings; Vloggers attract the attention of individuals through the atmosphere they create both physically and psychologically. A common communication language content should be established with the brandindividual-vlogger trilogy. Moreover, viewers tend to continue to follow the vloggers that they trust in their reputation. According to findings of the research, vloggers having a happy mood and friendly approach affect the perception of reputation. The use of vloggers with positive emotions such as happy mood and friendly personality in brand communication increase the demand of the audiences. Furthermore, the products and suggestions recommended by such vloggers are respected by the audiences.Since the limitation of the study includes convenience sampling, limits the generalizibility, it can be suggested that the research can be applied to different demographic and psychographical features. Additionally, comparison between different vloggers' content categories can be considered in future studies.

\section{Kaynakça / References}

Alikılıç, Ö. ve Onat, F. (2007). Bir halkla ilişkiler aracı olarak kurumsal bloglar. Journal of Yasar University, 8(2),899-927.

Berryman R. ve Kavka, M. (2017). I guess a lot of people see me as a big sister or a friend: The role of intimacy in the celebrification of beauty vloggers. Journal of Gender Studies, 26(3), ss.307-320.

Biel, J. I. ve Gatica-Perez, D. (2012). The good, the bad, and the angry: Analyzing crowdsourced impressions of vloggers, Proceedings of the Sixth International Conference on Weblogs and Social Media, 407-410.

Buttle, F.A (1998). Word of mouth: Understanding and managing referral marketing. Journal of Strategic Marketing, 6(3), 241-254.

Chaudhuri, A. (2002). How brand reputation affects the advertising-brand equity link. Journal of Advertising Research, 42(3), 33-43. 
Chen-Hsun H., Kuang-Hui, C., Hsin, C., Anastasia, P., (2015). Can internet blogs be used as an effective advertising tool? The role of product blog type and brand awareness. Journal of Enterprise Information Management, 28(3), 346-362.

Dahlen, M., Granlund, A. ve Grenros, M. (2009). The consumer perceived value of non-traditional media: Effects of reputation, appropriateness and expense. Journal of Consumer Marketing, 26 (3), 155-163.

Doyle, D. J., Heslop, A.L., Ramirez, A. ve Cray, D. (2012). Trust intentions in readers of blogs. Management Research Review, 35(9), 837-856.

Erdoğan, İ., Keloğlu, E. ve Durmuş, N. (2005). Kitle iletişiminde pozitivist ampirik geleneğin kuruluşu: Lazarsfeld ve yönetimsel araştırmalar. Gazi Üniversitesi Illetişim Dergisi, 20(2), 1-48.

Filieri, R. (2015).What makes online reviews helpful? A diagnosticityadoption framework to explain informational and normative influences in e-wom. Journal of Business Research, 68(6), 1261-1270.

Filieri, R. ve McLeay, F. (2014). E-wom and accommodation: An analysis of the factors that influence travelers' adaptation of information from online reviews. Journal of Travel Research, 53(1), 44-57.

Fiore, A., L. Taylor, Mendelsohn, G. ve Hearst, M. (2008). Assessing attractiveness in online dating profiles. In Proc.of SIGCHI.

Hansen, D.L., Shneiderman, B. ve Smith, M.A. (2011). Analyzing social media networks with nodexl. Burlington, MA: Elsevier.

Hsu, Y. H. ve Tsou, H.T. (2011). Understanding customer experiences in online blog environment. International Journal of Information Management, 31, 510-523.

Johnson, T.J ve B.K., Kaye (2004). Wag the blog: How reliance on traditional media and the internet influence the credibility perception of weblogs amog blog users. Journalism and Mass Communication Quarterly, 81(3), 622-42

Katz, E. (1957). The two-step flow of communication: An-up-to-date report on an hypothesis. Public Opinion Quarterly, 21, 61-78.

Kniffin, K. M. ve Wilson, D.S. (2004). The effect of non-physical traits on the perception of physical attractiveness: Three naturalistic studies. Evolution and Human Behavior, 25(2), 88-101. 
Lee J.E. ve Watkins, B. (2016). Youtube vloggers' influence on consumer luxury brand perceptions and intentions. Journal of Business Research, 69, 5753-5760.

Liljander, V., Gummerus, J. ve Söderlund, M. (2015). Young consumers' responses to suspected covert and overt blog marketing. Internet Research, 25(4), 610-632.

Lim, K., Sia, C., Lee, M. ve Benbasat, I. (2006). Do i trust you online, and if so, will i buy? an empirical study of two trust-building strategies. Journal of Management Information Systems, 23( 2), 233-266.

Malaga, R. A. (2001). Web-based reputation managment systems: problems and suggested solutions. Electronic Commerce Research, 1(4), 403-417

McQuail,D. ve Windahl, S. (2010). İletişim modelleri -kitle iletişim çalışmalarında. çev. Konca Yumlu. Ankara: İmge.

Milewicz, J. ve Herbig, P. (1994). Evaluating the brand extension desicion using a model of reputation building. Journal of Product and Brand Management, 1(3), 39-47.

Mishne, G.( 2005). Experiments with mood classification in blog posts. Style 2005-Proceedings of the 1st Workshops on Stylistic Analysis of Text for Information Access.

Peltekoglu, F. B. ve Akbayır, Z. (2010). Kurumsal iletiş̧imde bloglar: Türkiye'deki bilişim șirketlerinin kurumsal blog uygulamaları üzerine bir inceleme. 2.Uluslararası Yeni Medya ve Interaktivite Konferansi, Istanbul: 28- 30 Nisan 2010, http://www.filizbalta peltekoglu.com/903.pdf, (Erişim: 15.10.2018).

Sanchez-Villar, J., Bigne, E. ve Aldas-Manzano, J. (2017). Blog influence and politic activisim: An emerging and integrative model. Spanish Jounal of Marketing, 21, 102-116.

Sharma, S. (1996). Applied multivariate techniques. John Wiley \& Sons, Inc.

Tosun, N . (2014). Marka değeri yaratmada reklam ile halkla ilişkiler arasındaki etkileşim. Galatasaray Üniversitesi İletişim Dergisi, 6 (6), 181-199.

Turan, N.(2007). Yeni medya ve gazetecilik, Ankara Üniversitesi, Sosyal Bilimler Enstitüsü, Yayınlanmamış Yüksek Lisans Tezi. 
Uzunoğlu E. ve Kip, S.M. (2014). Brand communication through digital influencers: Leveraging blogger engagement. International Journal of Information Management, 34, 592-602.

Vargo, S. L. ve R. F. Lusch. (2004). Evolving to a new dominant logic for marketing. Journal of Marketing, 68(1), 1-17.

Veer, E. (2013). The routledge companion to digital consumption içinde "virtually 'secret' lives in 'hidden' communities ss.148-158 Edited by: Russel W. Belk ve Rosa Llamas (editörlü kitap)

www.tdk.gov.tr ; (erişim tarihi 10.04.2018)

Yaylagül, L. (2010). Kitle iletişim kuramları egemen ve eleştirel yaklaşımlar. Ankara: Dipnot Yayınları.

Yueh H.P., Chen, T.L., Chiu, L.A. ve Lin, W.C. (2013). Exploring factors affecting learner's perception of learning information and communication technology: A hlm analysis of a national farmers' training program in Taiwan. Educational Technology And Society, 16, 231242.

Zaichkowsky, J. L. (1985). Measuring the involvement construct. Journal of Consumer Research, 12, 341-352.

Zehrer, A., Crofts, J.C. ve Magnini, V.P. (2011).The perceived usefulness of blog postings: An extension of the expectancy disconfirmation paradigm. Tourism Management, 32(1), 106-113.

\section{Kaynakça Bilgisi / Citation Information}

Bayazıt, Z. Durmuş, B. Yıldırım, F.(2019). Pazarlama iletişim aracı olarak yeni medyada dijital etkileyiciler: Vloggerların karakteristik özellikleri ve bilgi birikimi tiplerinin vlogger itibarına etkisi üzerine bir araştırma. OPUS-Uluslararası Toplum Araştırmaları Dergisi, 11(18), 180-204. DOI: 10.26466/opus.526579 